Pamiętnik Literacki 2019, 3, s. 131-147

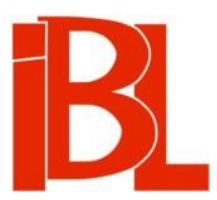

Noce arabskie Leśmiana

Piotr Łopuszański 


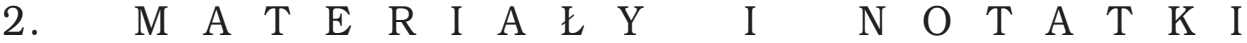

Pamiętnik Literacki CX, 2019, z. 3, PL ISSN 0031-0514

DOI: $10.18318 / \mathrm{pl} .2019 .3 .9$

PIOTR ŁOPUSZAŃSKI Warszawa

\section{NOCE ARABSKIE LEŚMIANA}

Gdy 22 I 1912 Bolesław Leśmian obchodził 35 urodziny, nie miał w swoim dorobku jeszcze żadnej wydanej książki. Mieszkał w tym czasie w Paryżu przy ulicy Vavin 13 i przygotowywał do druku debiutancki zbiór wierszy. Jak na początkującego poetę czynił to trochę późno. Pamiętajmy, że o blisko dwa lata od Leśmiana młodszy Leopold Staff (urodzony 14 XI 1878) miał już na koncie sześć tomów poezji, w tym wybitne (Gałaź kwitnaca, Uśmiechy godzin), trzy dramaty i poemat Mistrz Twardowski.

Leśmian zaś poza tym, że publikował wiersze i prozę poetycką w periodykach oraz antologiach, był recenzentem teatralnym i literackim, autorem szkiców o rytmie, filozofii Bergsona, sztuce teatralnej, artykułów pisanych po śmierci Tołstoja i Konopnickiej.

Rok 1912 miał się okazać przełomem. Już wcześniej, przed wyjazdem do Paryża, Leśmian złożył w wydawnictwie Jakuba Mortkowicza zbiór wierszy (jeszcze bez tytułu). Z Francji dosłał wydawcy dwa nowe cykle poetyckie. Nie był jednak w stanie zdecydować się na tytuł zbioru ani na selekcję obszernego materiału. Lubował się w „pakownych” tomach. Można rzec, iż miał zupełnie inne upodobania pod tym względem niż młodszy od niego (a często mylony z uwagi na podobieństwa pseudonimów) Jan Lechoń, któremu wystarczyło zebrać kilka lub kilkanaście wierszy, by wydać tomik. Niepewny co do wartości swoich utworów, Leśmian poprosił Zenona Przesmyckiego, byłego redaktora "Chimery”, o pomoc „w układzie tomu”.

W liście wysłanym do Miriama najprawdopodobniej w początku grudnia 1911 poeta wyznawał: „Piszę tak dużo, żem nigdy tyle nie pisał”. Przygotowywał wiersze do kolejnego tomu (jak wiadomo, ukazał się on dopiero latem 1920). Zapowiadał, że wkrótce przystapi do pracy nad dramatem (prawdopodobnie chodziło o Skrzypka Opętanego). Wspominał również o zleceniach od Mortkowicza: „Mam od niego kilka zamówień (Bajki arabskie, książka oryginalna dla dzieci i przekład De Costera) i to mi też dużo czasu zabiera" 1 .

Przekładu De Costera (zapewne Dyla Sowizdrzała) poeta nie dokonał². Jacek

$1 \quad$ B. Le śm i a n, list 81. W: Dzieła wszystkie. Zebrał i oprac. J. Trzn a de 1. [T. 4:] Utwory dramatyczne. - Listy. Warszawa 2012, s. 374. Początek grudnia 1911 jako prawdopodobny czas wysłania listu podaje edytor na podstawie informacji zawartej w karcie pocztowej poety z 12 XII 1911. Leśmian nie datował na ogół swojej korespondencji; wyjątek stanowiły pisma urzędowe. Karty pocztowe, na których zachowały się stemple, są źródłem naszej wiedzy o momencie ich wysłania, natomiast daty powstania listów trzeba ustalać na podstawie ich treści.

2 Autorem najbardziej znanego spolszczenia, wydanego w r. 1955, był J. Rog ozińs ki. 
Trznadel w przypisie do cytowanego listu Leśmiana uznał, iż w zamówieniu Mortkowicza chodziło o Klechdy sezamowe i, być może, Przygody Sindbada Żeglarza ${ }^{3}$. Roman Zimand w artykule zamieszczonym w Studiach o Leśmianie stwierdzał:

Poprawniej jednak wydaje się rozumieć je [tj. słowa $z$ listu] inaczej: Leśmian ma na myśli nie dwa, lecz trzy zamówienia: bajki arabskie, jakąś drugą książkę dla dzieci, która miałaby być nie - jak bajki - opracowaniem, lecz czymś oryginalnym, i wreszcie przekład De Costera ${ }^{4}$.

Zimand rozważał dwie hipotezy: albo bajki arabskie to Klechdy sezamowe, a oryginalna książka dla dzieci to Przygody Sindbada Żeglarza, albo też jako wykonane przez poetę zamówienie bajek należy rozumieć Klechdy sezamowe i Przygody Sindbada Żeglarza, natomiast oryginalną książką dla dzieci miały być Klechdy polskie. To tłumaczyłoby odrzucenie tej pracy przez Mortkowicza, gdyż Leśmian stworzył Klechdy polskie z myśla o czytelniku dorosłym. Niepotrzebnie Zimand dodał jeszcze ,jakiś tekst, którego Leśmian nigdy nie napisał i o którym nic nie wiemy" 5 . To mnożenie bytów ponad potrzebę.

Trznadel w swym Kalendarium leśmianowskim zarzucił Zimandowi, iż „nie uwzględnił jeszcze trzeciej ewentualności”: że słowa „książka oryginalna dla dzieci” to rozwinięcie słów „bajki arabskie” 6 . Zarzut nietrafny, bo tę hipotezę Zimand przedstawił jako pierwsza, podając, że jej zwolennikiem jest Trznadel.

Gdy czyta się list Leśmiana, ma się wrażenie, że poeta myślał o trzech zamówieniach: 1) bajkach arabskich, 2) książce oryginalnej dla dzieci, 3) przekładzie.

A skąd w ogóle to zlecenie? Jan Brzechwa, brat stryjeczny Leśmiana (ich ojcowie, Aleksander Lesman i Józef Lesman, byli braćmi), pisał w swoim wspomnieniu (Niebieski wycieruch):

Leśmian związany był $\mathrm{z}$ wydawnictwem Mortkowicza, a ponieważ wciąż potrzebował pieniędzy, czynił nieustające zabiegi o wydostanie coraz to nowych zaliczek. W ten sposób powstały Klechdy sezamowe i Przygody Sindabda Żeglarza, a wreszcie - Klechdy polskie ${ }^{7}$.

Sęk w tym, że poeta wtedy jeszcze nie współpracował z Mortkowiczem jako wydawca. Dopiero w przyszłości miał opublikować u niego swoje książki. Zapewne zaliczki na poczet kolejnych utworów odpowiadały Leśmianowi. Miał bowiem na utrzymaniu żonę, Zofię z Chylińskich, i dwie córki. Pod koniec 1911 r. starsza, Maria Ludwika Emma, miała 6 lat, młodsza, Wanda Irena Zofia, liczyła zaledwie 3 lata. Stąd podjęcie się przez Leśmiana pracy recenzenta tomików poetyckich w dodatku literackim do „Nowej Gazety” oraz recenzenta teatralnego w „Kurierze Warszawskim”, „Kulturze Polskiej” i „Nowej Gazecie”.

Poeta otrzymał propozycje od Mortkowicza i ją przyjął, nie tylko z powodów finansowych. Gdyby mu temat nie odpowiadał, odrzuciłby ją. Warto pamiętać, że

3 J. Trznadel, przypis 3 do listu 81 Leśmiana (w: Dzieła wszystkie, [t. 4], s. 374).

4 R. Zi m a nd, Preliminaria do klechd Leśmiana. W zb.: Studia o Leśmianie. Red. M. Głow i ń s ki,

J. Sławiński. Warszawa 1971, s. 376.

5 Ibidem.

6 J. Trzn a d el, Kalendarium leśmianowskie. Życie i twórczość w układzie chronologicznym. Warszawa 2016, s. 111.

7 J. Brzechwa, Niebieski wycieruch. W zb.: Wspomnienia o Bolesławie Leśmianie. Red. Z. J astrzębski. Lublin, 1966, s. 90-91. 
w 1910 r. odmówił Feldmanowi napisania do „Krytyki” o Oziminie Berenta, „a to z powodu zbyt niejasnego odgłosu", który w sobie znalazł po lekturze ${ }^{8}$.

Kiedy Mortkowicz zaproponował Leśmianowi ułożenie bajek wschodnich, wykorzystujących motywy z baśni z Tysiaca i jednej nocy ${ }^{9}$ ? Z listu do Miriama wynikałoby, że jesienia 1911. Jednakże na ten temat poeta mógł rozmawiać $\mathrm{z}$ wydawca wcześniej. Już od dłuższego czasu zajmowały go literatura i mitologia orientalna. W szkicu Bezkrólewie ducha opublikowanym 20 VIII 1910 na łamach „Prawdy” Leśmian pisał:

Za czasów Mahometa istniało jeszcze plemię Azra, z którego pochodziła matka proroka. Plemię to było dotknięte losem osobliwym i nieodpartym: chwila miłości była dla niego jednocześnie chwila śmierci. Kto pokochał - ten umierał ${ }^{10}$.

Co więcej, w tym okresie poeta wprowadzał w swojej poezji motywy i postaci literackie $\mathrm{z}$ baśni arabskich. Sidi-Numan ukazał się w marcu $1911 \mathrm{w}$ warszawskiej „Sztuce”. Poeta wykorzystał tu wątek fabularny z tomu 10 Tysiaca i jednej nocy w edycji Antoine’a Gallanda. W lipcu tego samego roku „Miesięcznik Literacki i Artystyczny” zamieścił Nieznana podróż Sindbada Żeglarza. W poemacie przyczyną podjęcia podróży była niechęć dziewczyny:

$$
\begin{aligned}
& \text {...̇e mi się dziewczę upatrzone wzbrania, } \\
& \text { Nieobecnością ciała w mym objęciu } \\
& {[\ldots \ldots \ldots \ldots \ldots \ldots \ldots \ldots} \\
& \text { Więc ja na przekór sobie i dziewczęciu } \\
& \text { Tej się nieznanej podjąłem podróży, } \\
& \text { By wlec swe głody po morzach dziesięciu! }{ }^{11}
\end{aligned}
$$

Opowieści z cyklu Tysiaca i jednej nocy powstały za panowania dynastii Abbasydów w X wieku i wykorzystywały wątki, legendy oraz mity z jeszcze dawniejszych czasów. Najstarszy manuskrypt pochodzi z VIII wieku i nosi tytuł Tysiąc opowieści. Niczym w palimpseście nawarstwiły się tu motywy z różnych epok, tradycji i religii. Są wątki zaczerpnięte $z$ dawnej religii Persów, skodyfikowanej przez Zaratusztrę, a także wywodzące się $z$ okresu wcześniejszego i $z$ wiary w demony. Sa motywy rodem z Egiptu, Indii i nawet $z$ Chin - odległych, lecz powiązanych stosunkami handlowymi $z$ Persją. Na to nałożyły się kultura i obyczajowość arabska oraz religia muzułmańska. Powstały różne wersje i związane z tym edycje. Najsłynniejsza była tzw. edycja bulacka, w której jednak zabrakło słynnej opowieści o Aladynie i jego cudownej lampie.

Do Europy opowieści te dotarły jeszcze w średniowieczu (odpowiedzią na nie był Dekameron Boccaccia). Dzięki przekładowi na język francuski dokonanemu

B. Leś mi a n, list 78. W: Dzieła wszystkie, [t. 4], s. 370.

W literaturze przedmiotu funkcjonuje również tytuł Tysiąc nocy i jedna. Najobszerniejszy, 9-tomowy wybór, opublikowany przez Państwowy Instytut Wydawniczy, nosi tytuł: Księga tysiaca ijednej nocy (1973-1976).

B. Leś mi a n, Bezkrólewie ducha. „Prawda” 1910, nr 34, z 20 VIII. Przedruk w: Dzieła wszystkie, [t. 2:] Szkice literackie (2011), s. 81.

B. Le ś mi a n, Nieznana podróż Sindbada Żeglarza. W: Poezje zebrane. Oprac. A. M a dy d a. Wstęp M. J akit ow i cz. Toruń 1993, s. 129. 
przez Gallanda, który w latach 1704-1712 na podstawie rękopiśmiennej wersji wydał drukiem Une Mille et une nuit (w 12 tomach), $\mathrm{z}$ baśniami wschodnimi zapoznały się szerokie kręgi czytelników.

W Europie zapanowała moda na Orient. Motywy wschodnie wykorzystywali Wolter, Monteskiusz, Goethe, Byron. Jan Potocki w Rękopisie znalezionym w Saragossie wykazał ogromna wiedzę o kulturze muzułmańskiej, ale i dowiódł swojej fascynacji tradycją rodem $z$ baśni z Tysiaca i jednej nocy. Ulubionym bohaterem Nikołaja Gumilowa był Sindbad Żeglarz jako symbol wolnego ducha. Oryginalna powieść o Sindbadzie znajduje się w trzecim tomie Tysiaca i jednej nocy.

Za króla Stanisława Augusta Poniatowskiego pijar Łukasz Sokołowski opublikował u Grölla, w latach 1767-1769, polski przekład edycji Gallanda. Nosił on tytuł Awantury arabskie, lub Tysiac nocy i jedna, $w$ języku francuskim przez J. M. P. Galland wydane, a świeżo najęzyk polski dla publicznej satysfakcji przettumaczone.

W roku 1819 w Wilnie ukazała się 6-tomowa edycja Józefa Zawadzkiego, oparta na przekładzie Gallanda. W roku 1873 Jan Breslauer ogłosił drukiem nowe wydanie Tysiaca i jednej nocy. W roku 1898 u Wilhelma Zuckerkandla w Złoczowie wyszło polskie tłumaczenie edycji Gallanda w 12 tomikach ${ }^{12}$.

$Z$ pewnością Leśmian znał opowieści arabskie, najprawdopodobniej $z$ polskich przekładów, być może też z wydań francuskich, choć gdy jako notariusz deklarował, iż włada językami obcymi, nie wspomniał, że jednym $z$ nich jest francuski (a przecież wymieniano go jako tłumacza Verlaine'a i Paula Forta! ${ }^{13}$ ). W kwestionariuszu osobowym znajdującym się w zamojskim archiwum poeta wymienił tylko znajomość w mowie i w piśmie języka rosyjskiego. Niewykluczone więc, że baśnie z Tysiąca i jednej nocy poznał w wersji rosyjskiej - 3-tomowe wydanie $z$ przekładu francuskiego ukazało się w Moskwie w latach 1889-1890. Być może, jakąś pomocą służył poecie Antoni Lange, który przecież tłumaczył z literatur wschodnich.

Badacze zastanawiali się, jakie teksty służyły Leśmianowi za podstawę, gdy pisał on swoje utwory oparte na motywach wschodnich opowieści. Marian Pankowski w powstającej na początku lat sześćdziesiątych w. XX, a wydanej po francusku w Brukseli w r. 1967 pracy Leśmian. La révolte d'un poète contre les limites ${ }^{14}$, uznał,

12 O recepcji baśni wschodnich pisali m.in. W. O1 k u s z (Polska recepcja „Tysiaca ijednej nocy” $w$ dobie pozytywizmu. „Pamiętnik Literacki” 1987, z. 4), J. Rudnick a („Tysiac nocy i jedna” $w$ kulturze literackiej polskiego oświecenia. Jw., 1998, z. 3; Recepcja opowieści z cyklu „Tysiac nocy i jedna” $w$ piśmiennictwie polskim. Jw., z. 4) oraz J. W a w ry k w rozprawie doktorskiej „Klechdy sezamowe” “ „Przygody Sindbada Żeglarza” jako prolegomena do twórczości poetyckiej Bolesława Leśmiana, obronionej na Uniwersytecie Śląskim w 2012 r. i umieszczonej w Internecie, na stronie: https://rebus.us.edu.pl/bitstream/20.500.12128/5320/1/Wawryk_Klechdy_sezamowe_i_Przygody_Sindbada_Zeglarza.pdf (data dostępu: 24 VII 2019).

13 O przekładach z Verlaine’a są wzmianki H. Hertza-Barwiń skiego, J. Brzechwy i W. Słob odnika we Wspomnieniach o Bolesławie Leśmianie (Red. Z. Jastrzębski. Lublin 1966). O tłumaczeniach z P. Forta (i E. Verrhaerena) pisał A. Po t o c k i w Polskiej literaturze wspótczesnej (cz. 2. Warszawa 1912, s. 329). Informacje na temat Leśmianowskich przekładów z literatury francuskiej pojawiają się również w encyklopediach z początku XX wieku. Nigdzie jednak nie wymienia się tytułów utworów (tylko we Wspomnieniach o Bolesławie Leśmianie można znaleźć na s. 87 napomknięcie Brzechwy o Skrzypcach jesieni Verlaine’a) ani nie podaje się, czy zostały te przekłady gdzieś opublikowane.

14 M. Pank ow ski, Leśmian. La révolte d'un poète contre les limites. Bruxelles 1967. Wersja pol- 
iż były to przekłady na francuski, tj. wspomniane tłumaczenie dokonane przez Gallanda i Le Livre des Mille nuits et une nuit Josepha Charles'a Mardrusa. Ukazało się ono w 1900 r. i zostało wznowione w latach 1908-1911. Problem w tym, że przekład Gallanda poddawano rozmaitym przeróbkom i skrótom. Nie wiadomo, z której wersji poeta korzystał.

Zimand przypuszczał, iż Leśmian znał edycję Zuckerkandla, gdyż za nią powtórzył imię żony Aladyna, Badrulbudury, stąd pochodzi też imię Piruza z pierwszej podróży Sindbada Żeglarza. Piruza jest bohaterką Historii o Kodadadzie i braciach jego. Innym źródłem mógł być przekład Mardrusa z drugiego wydania, z lat 19081911. Miała za tym przemawiać szata graficzna księgi opisanej przez poetę we wstępie do Baśni o Aladynie i o lampie cudownej. Trochę to słaba poszlaka.

Niewykluczone, iż Leśmian czytał także tłumaczenie niemieckiej przeróbki Alberta Ludwiga Grimma, Powieści z tysiaca i jednej nocy, które ukazało się nakładem Gebethnera i Wolffa. Zimand znał tylko wydanie trzecie, z 1893 roku. Po raz pierwszy przekład ten wyszedł po polsku w 1872 r. i do końca XIX stulecia miał cztery wydania, a do drugiej wojny światowej był wznawiany kilkunastokrotnie. Ta wersja stała się więc najpopularniejszą parafrazą baśni arabskich w Polsce.

Jak wiadomo, Klechdy sezamowe zawierały sześć opowieści: Baśń o rumaku zaklętym, Ali Baba i czterdziestu zbójców, Rybak i Geniusz, Opowiadanie króla Wysp Hebanowych, Baśń o Aladynie i o lampie cudownej, a także opowieść O pięknej Parysadzie i o ptaku Bulbulezarze.

W wydanym przez Gebethnera i Wolffa przekładzie parafrazy Grimma znalazły się odpowiedniki pięciu $z$ nich (oprócz opowieści o Aladynie). Dodatkowo jest tu Siedem podróży Sindbada-Żeglarza - a więc inspiracja Przygód Sindbada Żeglarza. O tym, że Leśmian musiał znać tę edycję, świadczy fakt, że u niego w pierwszej przygodzie Sindbada król wyspy, na którą przybył bohater, nazywa się Miraż, a zły czarownik nosi imię Degial. Zdaniem Zimanda, tylko w adaptacji Grimma w wersji Gebethnera i Wolffa obie postaci noszą takie imiona. Sam Degial wzięty jest z przekładu Gallanda. U Mardrusa nie występuje. Kolejny dowód stanowi określenie „Indianin” na właściciela czarodziejskiego rumaka w Baśni o rumaku zaklętym. W przeróbce Grimma jest tak samo ${ }^{15}$.

Jako ósma opowieść u Grimma znalazła się w edycji Gebethnera i Wolffa Historia o przemienionym Sidi-Numanie, co oczywiście wiąże się z Sidi-Numanem z Sadu rozstajnego, a dodatkowo, jako dziesiąta - Historia o księciu Achmedzie i wróżce Pari-Banu. W lutym 1901 Leśmian posłał do „Chimery” „poemacik” Pari-Banu,

ska: Leśmian, czyli Bunt poety przeciw granicom. Przeł. A. Krzewicki. Lublin 1999. Polski przekład jest skandalem wydawniczym. Tłumacz bowiem oprócz tekstu Pankowskiego na nowo Z wersji francuskiej spolszczył także recenzje i szkice Leśmiana, zmieniając ich brzmienie (a przecież wystarczyło sięgnąc do wydania Szkiców literackich z r. 1959). Zamiast Bezkrólewia ducha jest w tym wydaniu Duchowe bezkrólewie, zamiast Opowieści nadzwyczajnych Poego są Opowieści niesamowite, zamiast Ludzi Odrodzenia są Ludzie Renesansu, a rzekome cytaty nie odpowiadają rzeczywistym słowom poety. Jakim sposobem taki przekład mógł się ukazać w wydawnictwie naukowym?

15 Zi m a nd, op. cit., s. 386. Przy okazji krytyk pisze o drugim wydaniu Klechd sezamowych z r.1936 (ibidem). Najwyraźniej pomylił się, bo w 1936 r. wznowiono (było to trzecie wydanie) Przygody Sindbada Żeglarza. 
o czym dowiadujemy się z jego korespondencji z Przesmyckim. Wyjaśnił przy tym Miriamowi: ,jest to rzecz pierwsza i może ostatnia, która pisałem $z$ wielkim spokojem, a częstokroć uśmiechem duszy, dlatego też bardzo ją pokochałem" ${ }^{16}$.

W kolejnym liście poeta wyraził obawy co do losu utworu:

Mam przykre i niczym nie odparte przeczucie, że mój poemat pt. Pari-Banu, który posłałem do „Chimery”, nie tylko nie będzie zakwalifikowanym do druku, ale nawet zaszczyconym jakąkolwiek odpowiedzią ${ }^{17}$.

Antoni Lange zawiadomił Leśmiana, że Miriam zamierza drukować poemat w skróceniu. Na karcie pocztowej z 23 VII 1901 wysłanej ze stacji Nowosokolniki, gdzie Leśmian przebywał u stryja Aleksandra, poeta wyznawał: „Otóż sam teraz widzę wiele wad w moim poemacie i dużo bym tam pragnął zmienić" 18 .

W komentarzu do listów Trznadel pisał: „Wszystko wskazuje na to, że zamieszczony w grudniu 1901 roku w "Wędrowcu" doskonały fragment Ze wspomnień dzieciństwa jest właśnie częścią poematu Pari-Banu" ${ }^{19}$. Jednak nic na to nie wskazuje, bo cóż miałaby wspólnego wróżka Pari-Banu z utworem, w którym poeta wspomina swoje dzieciństwo „w starej kamienicy”? Badacz nie przedstawił za swoją tezą żadnych argumentów.

Prawdopodobnie w okresie młodości Bolesław Leśmian czytał jakieś przeróbki baśni orientalnych, do których jako wnuk i bratanek warszawskich wydawców i księgarzy (ojciec poety również przez krótki czas zajmował się księgarstwem) miał dostęp lepszy, niż gdyby pochodził z rodziny uprawiającej inny zawód.

Parafraz baśni przeznaczonych dla dzieci było wiele. Ukazywały się drukiem nie tylko wybory opowieści, ale też poszczególne baśnie, np. warszawski wydawca Jan Breslauer w 1861 r. opublikował w przekładzie Sokołowskiego Historię Aladyna, czyli lampę cudowna oraz Historię Ali Baby i czterdziestu rozbójników.

Polska literatura XIX stulecia przeniknięta była Orientem. Motywy orientalne znaleźć można w twórczości Mickiewicza, Słowackiego, Micińskiego. Znajomością kultury arabskiej odznaczał się urodzony w Syrii Wincenty Korab-Brzozowski. W jego tomie Dusza mówiaca czytamy o „bajecznym gryfie orientalnych marzeń, Rokhu, „który Sindbada wyrwał lotem swej potegi z ostrowia, gdzie nie było ducha, i w gwiazd kręgi rzucił, i nurzał w rozkosz niebiańskich przerażeń" ${ }^{20}$.

Leśmian, drukując recenzję $\mathrm{z}$ tego tomu na łamach „Prawdy”, pisał o Brzozowskim:

B. Le śmi a n, list 10. W: Dzieła wszystkie, [t. 4], s. 299.

B. Leśmia n, list 11 . W: jw., s. 300.

B. Leśs mia n, list 13 (karta pocztowa), z 10/23 VII 1901. W: jw., s. 303.

J. Trzn a d e 1, przypis do listu 10. W: B. Le ś m i a n, Utwory rozproszone. - Listy. Warszawa 1962, s. 247-248. W edycji Dziet wszystkich ([t. 4], s. 300) Trzn a d el usuną przymiotnik „doskonały”, ale nadal twierdzi, że utwór „jest częścią poematu Pari-Banu”. Również w przypisie do wiersza Wspomnienie z tomu Łąka (po raz pierwszy ogłoszonego 1 I 1913) edytor wyraził przypuszczenie: „Utwór ten jest prawdopodobnie fragmentem poematu Pari-Banu, napisanego około 1901 r." (B. Leś mi a n, Poezje. Oprac. J. Trzn a de l. Warszawa 1965, s. 516). W edycji wierszy z Dziet wszystkich krytyk już nie powtarzał tej wątpliwej hipotezy.

Zob. B. Leś mi a n, Pod znakiem poetów. II. „Prawda” 1910, nr 13, z 26 III. Przedruk w: Dzieła wszystkie, [t. 2], s. 267. 
Orientalne dążenie do Duszy Powszechnej łączy się w nim z poczuciem pokory, z poczuciem maluczkości duszy jednostkowej, której udziałem jest - żałoba - i wieczne memento mori... ${ }^{21}$

Co ciekawe, 29 I 1911 w dodatku literackim do „Nowej Gazety” ukazała się kolejna recenzja tomu Dusza mówiąca. Edytor pism Leśmiana uznał, iż poeta jest jej autorem, chociaż sygnowano ją tylko inicjałami. Nie wiadomo więc, czy to Leśmian napisał ponownie o tym tomie. Byłby to jedyny przypadek dwukrotnego omówienia przezeń tej samej książki. Recenzja jest bardziej zdawkowa, ale utrzymana w podobnej stylistyce, co inne jego recenzje.

Przy pisaniu Klechd sezamowych poeta zapewne sięgnał także po przekłady Tysiaca i jednej nocy z francuskiego. Pytanie: czy Gallanda, czy Mardrusa? Za znajomością tekstu Mardrusa przemawia fakt, iż w wierszu Sidi-Numan nazywa ukochaną Aminę „białą”. „Biała” jest u Mardrusa, imię Amina pochodzi zaś z edycji Gallanda. Marian Pankowski zauważył, że klacz Sidi-Numana jest biała, tak jak w wersji Mardrusa. O maści nie ma w edycji Gallanda ani słowa.

Przekład Gallanda jest pozbawiony poetyckich wyrażeń, ornamentów. Leśmian na kanwie prostej opowieści kreuje własną historię, upoetycznia ją, uzupełnia wieloma szczegółami - ponosi go fantazja twórcza. Również Mardrus rzadko daje się porwać poetyckim sformułowaniom. Pankowski przytacza przykład Chryzeidy, która u Gallanda „ubrała się pośpiesznie i wyszła z pokoju”. U Mardrusa mamy już dokładniejszy opis: „podniosła się, ubrała w najpiękniejsze szaty, skropiła perfumami, zatknęła miecz, otworzyła drzwi pałacu i wyszła [...]".

Grzegorz Leszczyński wysunął w 1993 r. hipotezę, że Leśmian oparł się na edycji Julles'a Tallandiera Les Mille et une nuits z ilustracjami Luciena Laforge'a ${ }^{22}$. Data jej ukazania się, 1912 rok, stanowi kontrargument. Poeta część swojej wersji napisał pod koniec r. 1911, nie mógł więc opierać się na książce, która wyszła później. Dzieło Tallandiera zawiera opowieść o Aladynie, o Ali Babie i o Sindbadzie, zatem poeta miał sposobność wykorzystać je wyłącznie przy pracy nad Przygodami Sindbada Żeglarza.

Jeśli chodzi o ilustracje, to warto podkreślić, że w pierwszym wydaniu Klechd sezamowych z 1912 r. (opublikowanych $z$ datą: 1913) Jakub Mortkowicz zamieścił sześć kolorowych rysunków Edmunda Dulaca, modnego wówczas grafika, autora opracowania graficznego co najmniej dwóch różnych edycji baśni wschodnich.

Zastanawiające, iż leśmianolodzy nie poszli tropem edycji baśni wschodnich z ilustracjami Dulaca - jako źródła Klechd sezamowych. A przecież jeśli nie sam poeta, to przynajmniej Mortkowicz musiał owe edycje mieć.

Hanna Mortkowicz-Olczakowa pisała o ojcu, iż był koneserem pięknych książek. Tak zapamiętała wygląd Klechd sezamowych:

oprawne były w żółtozłote albo turkusowe płótno i zdobne obrazkami Dulaca, które dopełniały, w sposób zachwycający nas wówczas, opowieści o czarodziejskiej górze, skarbach Sezamu i dziwnym jeziorze, w którym pływały różnobarwne zaczarowane ryby ${ }^{23}$.

21 Ibidem.

22 Zob. G. Leszczyńs ki, Francuskie inspiracje baśni Leśmiana. „Guliwer” 1993, nr 2, s. 51-53.

23 H. Mortkowicz-Olczakow a, O Bolesławie Leśmianie. W: Bunt wspomnień. Warszawa 1959,

s. 113 . 
Pierwszą $\mathrm{z}$ adaptacji na język francuski było dzieło Hadji-Mazema Contes des Mille et une nuit, z 57 ilustracjami Dulaca, wydane w 1907 r. przez oficynę H. Piazza et Cie, która mieściła się w Paryżu przy ulicy Jacob pod numerem czwartym. W wersji tej znalazły się opowieści o rybaku i Geniuszu, królu Czarnych (czyli Hebanowych) Wysp, Ali-Babie i 40 rozbójnikach, o cudownym koniu. Były tam także historia Cadadada i jego braci oraz opowieści o księżniczce Deryabar, a więc baśnie, których Leśmian nie opracował.

W tym samym czasie w Londynie i w Nowym Jorku wyszła angielskojęzyczna adaptacja: Stories from Arabian Nights autorstwa Laurenca Housmana. Ona też zawierała ilustracje Dulaca. Wznowienie ukazało się w 1911 roku.

Z którejś z tych edycji korzystał Mortkowicz, skoro w swoim wydaniu dał rysunki Dulaca (fakt, że zamieścił tylko sześć ilustracji, świadczy o oszczędności wydawcy). Być może, podstawą była wersja angielska, tam bowiem okładka jest ceglasta, pomarańczowo-czerwona, a więc bliska opisowi Leśmiana. Za tym, iż tę właśnie ksiażkę miał Mortkowicz, świadczyłby tytuł, jaki - według listu skierowanego do poety przez Konrada Drzewieckiego (współpracownika Mortkowicza, tłumacza Nietzschego) - wydawca chciał nadać obu tomom: Noce arabskie ${ }^{24}$, co wprost nawiazywało do edycji angielskiej. Tom pierwszy, znany dziś jako Klechdy sezamowe, miał nosić tytuł Baśń o rumaku zaklętym i inne opowieści arabskie, tom drugi Przygody Sindbada Żeglarza. Ponadto - w książce angielskiej znalazły się opowieści zawarte w Klechdach sezamowych i Przygodach Sindaba Żeglarza, w tym historia Aladyna i jego lampy, której brakowało w wersji francuskiej, poza tym w Stories from the Arabian Nights zamieszczono siedem opowieści o podróżach Sindbada.

Problem w tym, że Leśmian nie znał angielskiego. Być może, ktoś mu pomógł, przekładając tekst albo też sięgnął on do znanych $z$ dzieciństwa opracowań i na ich kanwie stworzył własną wersję?

Przy okazji warto zauważyć, że poeta w 1913 r. opublikował w „Sztuce” wiersz Królewna Czarnych Wysp, który nawiązuje do opowiadania z Klech sezamowych.

Drzewiecki we wspomnianym liście zakwestionował tytuł zaproponowany przez Mortkowicza, a wzięty $\mathrm{z}$ wersji Housmana:

Mnie się ten tytuł nie podoba; więcej nawet, uważam go za nieodpowiedni i nie odpowiadający treści. $Z$ tego, co czytałem w tomie I, nic o żadnych nocach nie dowiedziałem się; mowa też ciągle o Persji, nie o Arabii $^{25}$.

Leśmian też wolał zmienić tytuł. Zaproponował: Klechdy sezamowe, i prosił, żeby nie nadawać wspólnego tytułu obu tomom.

Klechdy sezamowe ukazały się na przełomie listopada i grudnia 1912. Książka odnotowana została przez „Przewodnik Bibliograficzny” ze stycznia 1913 (nr 1). Wydanie z ilustracjami Dulaca kosztowało 3 ruble, bez ilustracji - półtora rubla.

Na karcie tytułowej podkreślono, że poeta był jedynie autorem opracowania literackiego, nie zaś samodzielnym twórcą. A przecież Leśmian zawarł na stronicach ksiażki wiele ze swej osobowości i poglądów. Oto wezyr wypowiada słowa, których twórcza Bolesława Leśmiana (w zb.: Wspomnienia o Bolesławie Leśmianie, s. 64). 
mogła użyć jakakolwiek z postaci świata Leśmianowskiego: „Czytałem w życiu swoim dużo bajek, więc wiem, że tylko człowiek samotny potrafi zbliżyć się do tajemnicy" ${ }^{26}$. Anna Szóstak pisała:

Literacka adaptacja tych baśni dowodzi niezbicie, że [Leśmian] odnalazł [...] tę cząstkę własnej osobowości, która pozwoliła mu powrócić do czasów, gdy był dzieckiem i egzystował w czarownej rzeczywistości tworzonej przez baśnie dzieciństwa. [...] Tego świata nie trzeba było nawet wymyślać, czekał gotowy już i w pełni ukształtowany ${ }^{27}$.

Poeta, wzorem innych adaptatorów, odrzucił szkatułkową kompozycję oryginału (naśladowaną z lubością przez Jana Potockiego w Rękopisie znalezionym w Saragossie). Pominął postać Szeherezady, której opowieści stanowią ramę kompozycyjną. W wersji Leśmiana niemal każda $z$ historii jest samodzielną całością. Ślady kompozycji szkatułkowej można zauważyć tylko w baśni Rybak i Geniusz oraz w powiązanym z nią Opowiadaniu króla Wysp Hebanowych.

Leśmian często rozmijał się z pierwowzorem. W oryginalnej Opowieści o rybaku i dżinnie ubogi rybak „miał żonę i troje dzieci. Swoim zwyczajem zarzucał sieci codziennie cztery razy; nigdy mniej ani więcej” ${ }^{28}$. W Leśmianowskiej baśni Rybak i Geniusz bohater ma czworo dzieci i dlatego - umiejąc rachować tylko do czterech cztery razy zarzuca sieci:

Liczę zaś do czterech,

Bo mam czworo dzieci! ${ }^{29}$

Liczba cztery okazała się na tyle ważna dla poety, że zmienił symboliczną trójkę dzieci (często występującą w baśniach i legendach) na czwórkę. Carl Gustav Jung napisałby, iż Leśmian realizował w opowieści archetyp Czwórcy, pełni, odpowiednika Jaźni. Jest to też nawiązanie do czterech stron świata, czterech pór roku, czterech żywiołów i czterech temperamentów starożytnej medycyny.

W oryginalnej opowieści rybak złowił w sieć zdechłego osła, garnek pełen piasku i mułu, skorupy naczyń. Za czwartym razem trafił na miedziany dzban z zamkniętym w niej pieczęcią Sulejmana dżinnem (w islamie Salomona nazywa się Sulejmanem). U Leśmiana rybak chwyta w sieć piasek (co jest fałszywym obrazem, gdyż w sieci są oka, a więc piasek by przez nie przeleciał), za drugim razem - trawę morska, za trzecim razem w sieci znalazł się ił morski. Nie ma mowy o martwym zwierzęciu i większych twardych przedmiotach. Za czwartym razem rybak wyłowił miedzianą szkatułkę, na której była pieczęć króla Salomona. W oryginalnej baśni bohater wypowiada słowa: „żyjemy u kresu czasu”, a więc uważa, iż koniec świata jest bliski. U Leśmiana podobna konstatacja nie pojawia się.

Klechdy sezamowe zostały uznane w omówieniu Jana Lorentowicza za piękne dzieło wśród „wydawnictw gwiazdkowych”. W podobnym tonie pisała Stanisława

B. Leśmia n, Rybak i Geniusz. W: Dzieła wszystkie, [t. 3:] Baśnie i inne utwory proza (2012), s. 309.

A. Szó s tak, Fantastyka „Klechd sezamowych”. W zb.: Twórczość Bolesława Leśmiana. Studia i szkice. Red. T. Cieśla k, B. St el m a s z c zy k. Kraków 2000, s. 296.

Opowieść o rybaku i dżinnie. W zb.: Księga tysiaca ijednej nocy. Wybór, wstęp W. Ku bia k. Przeł. A. Czapkiewicz, A. Kmietowicz, W. Kubiak, K. Skarżyńska-Bocheńska. Wiersze przeł. J. Fi c owski. Warszawa 1977, s. 22.

Le śm i a n, Rybaki Geniusz, s. 290. 
Szadurska, poetka (której tomiki Leśmian wcześniej recenzował). Małgorzata Gorczyńska bez powołania się na jakiekolwiek źródło stwierdziła, iż określenie „"wydawnictwa gwiazdkowe" [...] było zgodne $z$ założeniami wydawcy, choć niekoniecznie autora" ${ }^{30}$. Z listów poety jasno wynika, że dostał zamówienie na książkę dla dzieci i taką napisał, więc nie powinien się zżymać na klasyfikowanie Klechd sezamowych i późniejszych Przygód Sindbada Żeglarza jako utworów przeznaczonych dla młodego odbiorcy. Takich nie opartych na niczym konstatacji jest $\mathrm{w}$ pracy Gorczyńskiej sporo.

Anna Czabanowska-Wróbel interpretuje Klechdy sezamowe zgodnie $\mathrm{z}$ koncepcją Junga. W Baśni o pięknej Parysadzie [...] dostrzega jungowskie archetypy animy i animusa, Starego Mędrca. Poeta istotnie sięgał po archetypy (najwyraźniej widać to w Legendach tęsknoty drukowanych w 1904 r. w „Chimerze”) i - jak wspomniałem - nawet rozwijał archetypowe rozumienie świata, np. w Rybaku i Geniuszu.

Mimo iż Leśmian został zaprezentowany jedynie jako autor „opracowania”, w Klechdach sezamowych znaleźć można wyrażenia dla niego typowe: „Struga Złotosmuga”, „Góra Cmentarnica”, „Ścieżka Złotobrzeżka”. Dą̧-Samograj kojarzy mi się z ballada Dab z tomu Łaka. Wiersz Królewna Czarnych Wysp to poetyckie nawiązanie do opowieści o Królu Wysp Hebanowych.

Warto podkreślić, że w kolejnych wydaniach do tekstu Klechd sezamowych wprowadzono zmiany. W czasach PRL w edycji „Czytelnika” w klechdzie Król Wysp Hebanowych usunięto informację, że potwór jest ogromnym Murzynem. Pozostawiono potwora. Zrezygnowanie ze słowa „Murzyn”, a pozostawienie „potwora” było zdaniem Trznadla - „cenzurą swoiście polityczną, w stylu tak zwanego "poprawnego myślenia""31. Naturalnie, w latach pięćdziesiątych XX w. nie istniało jeszcze pojęcie „poprawności politycznej”, ale chyba właśnie ze względów propagandowych to słowo usunięto, mimo iż nie jest ono nacechowane negatywnie, lecz stanowi element opisu. Zresztą na ogół utwory literackie redaktorzy i edytorzy przycinali wedle swego gustu czy dyrektyw partyjnych.

Według Trznadla również „Indianin” z Baśni o rumaku zaklętym, który raz jest dobry, raz zły, „został wykluczony $z$ wydań powojennych, zapewne z podobnego powodu, co "potworny Murzyn""32. Zamieniono go na czarnoksiężnika. Moim zdaniem, ta zamiana wynikała $z$ faktu, iż w Persji czy Arabii nie było Indian. Tak więc w nowej wersji baśni Leśmiana pojawił się czarnoksiężnik: „Wtem - nagle - ni stąd, ni zowąd - wysunął się z tłumu jakiś czarnoksiężnik. Prowadził on za uzdę pięknego rumaka, na którym błyszczał złoty czaprak i złote siodło" ${ }^{33}$. Pierwotnie zdanie to brzmiało: „Wtem nagle - ni stąd, ni zowąd - wysunął się z tłumu jakiś Indyanin. Indyanin prowadził za uzdę pięknego rumaka, na którym błyszczał złoty czaprak i złote siodło" 34 .

„Indianina” przywrócono w wydaniu Baśni i innych utworów prozą w tomie Dziet wszystkich Leśmiana.

M. G o r c zy ń s ka, Miejsca Leśmiana. Studium topiki krytycznoliterackiej. Kraków 2011, s. 33.

J. Trznad el, Od wydawcy. W: Leśmi a n, Dzieła wszystkie, [t. 3:], s. 891.

Ibidem.

B. Le śm i a n, Baśń o rumaku zaklętym. W: Klechdy sezamowe. Wyd. 6. Warszawa 1978, s. 7.

B. Leś mi a n, Baśń o rumaku zaklętym. W: Klechdy sezamowe. Opracował ... Warszawa 1913 [postdat.], s. 3. 
W edycji tej Jacek Trznadel także wprowadził zmiany do tekstu Leśmiana: oprócz zmodernizowania pisowni zamieniał stale „jeno” z utworu poety na „tylko” jako bardziej współczesne. Uważam, że nie miał do tego prawa. Tak więc prawdziwy, oryginalny, „kanoniczny” tekst Leśmiana istnieje tylko w wydaniu pierwszym, z 1913 roku.

Można się zastanawiać, dlaczego utwór, który od lat należy do kanonu literatury dziecięcej, nie miał wznowień za życia poety. Dla porównania, ogłoszone drukiem w 1913 r. przez Gebethnera i Wolffa Awantury arabskie Makuszyńskiego doczekały się w ciagu 14 lat aż pięciu wydań. Jakościowo tekst Leśmiana przewyższa wersję Makuszyńskiego, więc brak wznowień musi budzić zdziwienie. Mortkowicz prowadził dość niezrozumiała politykę, np. popularne przed pierwszą wojną światową dzieła Nietzschego, które miały w ciagu kilku lat nawet po trzy edycje, w okresie międzywojennym nie zostały opublikowane ani razu.

Niedługo po ukazaniu się Klechd sezamowych zmarł ojciec poety, Józef Lesman. Stało się to 28 XII 1912. W młodości był redaktorem pisma „Przyroda i Przemysł”, pracował jako księgarz w Warszawie, a następnie został naczelnikiem kasy emerytalnej dla urzędników na Kolei Południowo-Zachodniej w Kijowie. Kilka ostatnich lat życia mieszkał w Warszawie.

Nekrolog zamieszczony w tygodniku „Świat” rzuca nowe światło na sprawę odejścia ojca poety z posady. W roku 1905 kasę emerytalną przekształcono w Kasę Pożyczkowo-Oszczędnościową. Jak podawał nekrolog, Józef Lesman był przeciwny takiemu rozwiązaniu:

Nie mogąc się pogodzić $\mathrm{z}$ tym, by instytucja, dla której poświęcił w ciagu 27 lat wszystkie swoje siły, została tak wbrew jego przekonaniom przeistoczona, podał się do dymisji. Otrzymawszy emeryturę, osiadł w umiłowanej przez siebie Warszawie ${ }^{35}$.

W ostatnich latach Józef Lesman mieszkał przy Kopernika 11 z drugą żoną, Helena $z$ Dobrowolskich. W tej samej kamienicy zamieszkiwał również poeta wraz z żoną.

Na początku stycznia na Starych Powązkach odbył się pogrzeb ojca Leśmiana. Poeta pisał do Miriama: „Przyjechałem w dniu pogrzebu”36. Z Mortkowiczem spotkał się niedługo potem. Zapewne stało się to w siedzibie wydawnictwa, w księgarni Centnerszwera i Spółki przy Marszałkowskiej 143. Leśmian relacjonuje słowa Mortkowicza: „Powiedział mi tylko, że jest ogromnie zadowolony z moich ksiag. Podniesie mi honoraria i wyda wszystko, cokolwiek napiszę" 37 . Najwyraźniej Mortkowicz docenił niezwykły talent poety, który w krótkim czasie stworzył trzy ciekawe dzieła: tom wierszy Sad rozstajny, Klechdy sezamowe i Przygody Sindbada Żeglarza. Czy należy wierzyć w słowa, że Mortkowicz wyda wszystko, cokolwiek Leśmian napisze? Być może, to typowe dla poety myślenie życzeniowe, ale po tych trzech dziełach wydawca mógł zapewnić go, że chętnie opublikuje inne jego teksty.

Zadziwiające, iż w żałobie poeta nic nie pisze o zmarłym, za to dzieli się z Miriamem opinią Mortkowicza o swych utworach. Nie ma też śladu pesymizmu 
w Przygodach Sindbada Żeglarza, który Leśmian, przygnębiony po stracie ojca, mógłby ujawnić. Utwory z tego okresu nie odznaczają się smutkiem czy młodopolską melancholią, przeciwnie - tchną optymizmem i pochwałą życia. Dopiero znacznie później poeta wrócił do postaci ojca. W wierszu *** (Bóg mnie opuścit - nie wiem, czemu...) pisał o jego śmierci:

Ojciec mój tak swą śmierć przeoczył,

Że idąc do dom - w grób się stoczył ${ }^{38}$.

Wedle relacji Jana Brzechwy - Józef Lesman wracał do domu z poczty (która mieściła się na placu Wareckim, dziś Powstańców Warszawy) i po drodze zmarł na atak serca.

W wierszu Wspomnienie z Napoju cienistego Leśmian przywoływał dzieciństwo i zabawę, którą zainspirowały zapewne baśnie $z$ Tysiąca i jednej nocy:

Przy śniadaniu patrzyłem w stół, jak w pustynię,

Śniąc, że na wielbłądzie jadę... Zbójcą jestem...

A ojciec, jakby wiedząc, że wielbłąd go wyminie,

Czytał dziennik ze spokojem i szelestem... ${ }^{39}$

W Przygodach Sindbada Żeglarza nie pojawia się nawet ślad żałoby. Zresztą wiele wskazuje na to, że tekst powstał jeszcze w Paryżu.

Książkę tę zaczęto składać we wrześniu 1912 - o czym zawiadamiał poetę Drzewiecki. Ukazała się ona w r. 1913, najprawdopodobniej w pierwszych miesiącach. Nie było sensu czekać z jej ogłoszeniem aż do Świąt Bożego Narodzenia. Zreszta już na kartach Klechd sezamowych zapowiadano Sindbada jako nowość wydawniczą.

$Z$ korespondencji Leśmiana wiemy, że napisał on też farse (najpewniej chodzi o Bajkę o złotym grzebyku), która pragnął wystawić ${ }^{40}$. Niebawem otrzymał ofertę od Lorentowicza, aby przełożył na język polski opowiadania fantastyczne Poego. Leśmian zabrał się do pracy. Przetłumaczył 20 nowel, które ukazały się w dwóch tomach w „Bibliotece Literacko-Artystycznej "Muzy"”, gdzie Lorentowicz ogłaszał wartościowe utwory literatury polskiej i światowej, m.in. Zygmunta Krasińskiego, Piotra Skargi, Jana Potockiego, Edgara Allana Poego. Tomy te zostały opublikowane przez firmę E. Wende i S-ka oraz Towarzystwo Akcyjne S. Orgelbranda.

W wydaniu pierwszym Przygody Sindbada Żeglarza ozdobione były pięcioma ilustracjami wykonanymi przez Józefa Toma, który był również autorem okładki. Mortkowicz-Olczakowa wspominała:

Przygody Sindbada Żeglarza miały mniej udaną i mniej świetna [niż Klechdy sezamowe - P. Ł.] oprawę wydawniczą, za to ich treść, pełna humoru i poetyckiego polotu, była już nie tylko szczęśliwą poetycką parafrazą znanych wątków, ale raczej oryginalną, odkrywczą fantazją samego Leśmiana ${ }^{41}$.

B. Le śmi a n, ${ }^{* * *}$ (Bóg mnie opuścit - nie wiem, czemu...). W: Dzieła wszystkie, [t. 1:] Poezje zebrane (2010), s. 430.

B. Leśmi a n, Wspomnienie. W: jw., s. 413.

B. Le śm i a n, list 93 (ze stycznia 1913). W: Dzieła wszystkie, [t. 4], s. 393. Jest tam mowa o tym, iż farsę czyta Śliwiński. Chodziło o Ludwika Śliwińskiego, dyrektora teatru „Nowości”. W liście 95 (w: jw., s. 395) poeta informował Miriama, że Rabski (krytyk i recenzent „Kuriera Warszawskiego”, Władysław Rabski) przeczytał farsę i oburzył się na jej „nieprzyzwoitość” oraz „trywialność”.

Mortkowicz-Olczakowa, op. cit., s. 113. 
Według katalogu cena edycji kartonowej wynosiła 1 rubel 80 kopiejek, a w oprawie 2 ruble 50 kopiejek. Na karcie tytułowej Sindbad opatrzony był podtytułem Powieść fantastyczna Bolesława Leśmiana, natomiast w katalogu nowości wydawniczych Mortkowicza zamieszczonym na końcu książki napisano: Przygody Sindbada Żeglarza. Oryginalna fantastyczna opowieść dla młodzieży ${ }^{42}$.

Drugie wydanie ukazało się w 1915 roku. Powoływał się na nie Pankowski, a mimo to Zimand wspominał o tej edycji jak o nieistniejącej ${ }^{43}$, chociaż odnotowuje ją spis publikacji sporządzony przez Mortkowicza.

W listopadzie 1936 wyszło wydanie trzecie. Tym razem Leśmian zrezygnował $\mathrm{z}$ drukowania u wdowy po Mortkowiczu (który popełnił samobójstwo w r. 1931), zapewne obawiając się niewypłacalności firmy. Przygody Sindbada Żeglarza opublikowała teraz oficyna „Biblioteka Polska”. Tom został starannie opracowany, zawiera piękne ilustracje, wykonane w Atelier Girs-Barcz. Recenzję tej edycji Sindbada ogłosił na łamach „Nowej Książki” Alfred Łaszowski. Podkreślił realizm szczegółów, a zarazem opisy bliskie halucynacjom. Docenił też pełną humoru postać wuja Tarabuka ${ }^{44}$.

Drugi z tomów $\mathrm{z}$ baśniami wschodnimi dla dzieci nosił już tym razem bardzo wyraźne piętno stylu Leśmiana. Włożył on wiele trudu, aby baśniom nadać osobisty charakter. Zdecydowanie odszedł od fabuł oryginału, zminimalizował wątki związane z okrucieństwem (jak grzebanie żywcem żon i mężów zmarłych współmałżonków czy zamordowanie przez Sindbada - przy użyciu piszczela - kobiety, która ze zmarłym mężem zamknięto w pieczarze), za to podkreślił egzotykę i cudowność zdarzeń. Fabuła poszczególnych przygód różni się od tej z Tysiąca i jednej nocy. Poeta zmienił też nazwę miasta Basra na Balsora.

W wersji Leśmiana dominuje humor, a nawet groteska. Autor wprowadził m.in. świetna postać wuja Tarabuka, opętanego manią literacka, niewolnika poezji. Tej postaci nie ma w oryginalnych opowieściach, podobnie jak złośliwego starucha, wpijającego się w osobę, która chcąc mu pomóc, bierze go na ramiona. Wówczas staruch dosiada nieboraka i go „ujeżdża”. Kojarzy się to ze sceną dosiadania pań w Ferdydurke. Czyżby Gombrowicz zapamiętał tę scenę z lektur dzieciństwa i, zmieniona, powtórzył w swojej powieści?

Bogusław Grodzki, pisząc w swej pionierskiej, cennej monografii o Przygodach Sindbada Żeglarza, sugeruje, iż Leśmian zaczerpnął motyw złośliwego starucha z opowiadania Poego William Wilson. A pamiętajmy, że poeta niemal równolegle tłumaczył opowieści amerykańskiego autora, m.in. tę właśnie nowelę. Grodzki błędnie stwierdza: „Wprawdzie wybór ten nie zawiera wspomnianego opowiadania, trudno jednak przypuszczać, że mógł nie znać tego słynnego opowiadania” ${ }^{45}$. Nie trzeba przypuszczać, gdyż Leśmian przełożył ów utwór. Nie rozumiem, skąd krytyk czerpał mylną informację, że poeta go nie przetłumaczył, wszak William Wilson

Takie samo sformułowanie znalazło się w prospekcie pod koniec tomu L. Ch or o mańskiego Pościg za słońcem z 1914 roku.

43 Zimand, op. cit.

44 A. Ła s zo w s k i, recenzja Przygód Sindbada Żeglarza. „Nowe Książki” 1937, nr 6 (czerwiec-lipiec).

45 B. Grodzki, Leśmianowska baśń nowoczesna. O „Przygodach Sindbada Żeglarza” Bolesława Leśmiana. Lublin 2012, s. 91. 
otwiera drugi tom Opowieści nadzwyczajnych w wydaniu „Biblioteki Literacko-Artystycznej "Muzy"”.

W oryginalnej wersji baśni wschodnich występuje dwóch Sindbadów. Jeden jest ubogiego stanu i pracuje jako tragarz. Spotyka on bogatego kupca, zwanego Sindbadem Żeglarzem. Ów Sindbad odziedziczył po ojcu „pieniądze, kosztowności i wiejską posiadłość", ale je roztrwonił. Wtedy wpadł na pomysł udania się w podróż „do obcych krajów i ludów”. Tam wzbogacił się na handlu, nabył wielu niewolników i wiele nałożnic, kupił domy i wiejskie posiadłości. U Leśmiana jest jeden Sindbad, chociaż później pojawia się jego sobowtór, Hindbad, który zabiera Sindbadowi ukochaną. Motyw sobowtóra występuje też w późnej poezji Leśmiana.

„Rodzice moi, umierając, zostawili mi w spadku tysiąc worów złota, tysiąc beczek srebra, sto pałaców, sto ogrodów i jeden trzonowy ząb mojego pradziadka [...]" czytamy w Przygodach Sindbada Żeglarza ${ }^{46}$. Jak widać, poeta $z$ humorem i dystansem podchodził do swego bohatera. Po śmierci rodziców Sindbad Leśmiana zamieszkał w pałacu $\mathrm{z}$ jedynym wujem Tarabukiem, poeta. $\mathrm{W}$ rodzinie autora wujem (tak zapewne można by go nazwać), który zajmował się poezją, był Antoni Lange, jego krewny (chociaż należał do bocznej linii). To on wprowadził Leśmiana do świata literackiego Warszawy i wymyślił mu pseudonim. Wspólnym przodkiem Leśmiana i Langego był Antoni Eisenbaum, pradziadek autora Laki i dziadek twórcy tomu opowiadań $W$ czwartym wymiarze. $\mathrm{W}$ przeciwieństwie do Tarabuka był wszakże Lange poetą cenionym w okresie Młodej Polski.

O walorach poezji Tarabuka można się przekonać, gdy przeczyta się początek jednego $\mathrm{z}$ jego wierszy:

\section{Morze - to nie rzeka, a ptak - to nie krowa!}

Szczęśliwy, kto kocha rymowane słowa! ${ }^{47}$

Tarabuk uznał, iż utwór jest piękny i prawdziwy. „Któż zaprzeczy prawdzie tych słów!" Inne zdanie miał natomiast Diabeł Morski, który przeczytawszy poezje Tarabuka, powiedział: „Nigdy jeszcze nie czytałem tak głupich, brzydkich i nieznośnych wierszy!"48. Diabeł Morski napisał list do „miłego siostrzeńca” Tarabuka, Sindbada. Pytał w nim, jak Sindbad może pod jednym dachem mieszkać „Z takim głupcem nieznośnym”. W liście tym zachęcał też młodzieńca do odbycia podróży:

\footnotetext{
Czeka cię bajka senna w zaklętej krainie I Królewna stęskniona, co $\mathrm{z}$ urody słynie, I skarby, i przepychy, i dziwy, i czary! Pędź na lotnym okręcie przez morza obszary, Zwiedzaj wyspy, półwyspy, lądy i przylądki, I najdalsze zatoki, najskrytsze zakąki ${ }^{49}$.
}

Tak więc to $z$ namowy Diabła Morskiego, pragnącego uwolnić Sindbada od towarzystwa wuja Tarabuka, młodzieniec wybiera się w podróż. Na tom składają się przygoda wstępna i siedem kolejnych, w których bohater odbywa różne wyprawy, przeżywa rozmaite przygody.

B. Le śmi a n, Przygody Sindbada Żeglarza. Wyd. 6. Warszawa 1977, s. 5.

Ibidem, s. 6.

Ibidem, s. 8.

Ibidem, s. 11. 
Poeta słowami jednego $\mathrm{z}$ bohaterów Klechd sezamowych wyraził własną wiarę: „Świat jest pełen czarów, zaklęć i tajemnic"50. Leśmian uwielbiał opowiadać baśnie swoim córkom, a gdy te podrosły, nawet obcym dzieciom. Musiał mieć ogromna przyjemność, pisząc o wuju Tarabuku, Sindbadzie i innych postaciach.

Jerzy Sosnowski widział w utworze Leśmiana powieść inicjacyjną, opartą na archetypach Junga ${ }^{51}$. U Junga proces rozwoju osobowości nazywa się procesem indywiduacji. Bohater mitów, legend zmaga się z Cieniem (a więc ze złem, które Jung uważa za ciemną stronę osobowości, nie zaś - za coś zewnętrznego), z animą (obrazem kobiety) lub animusem (męskim aspektem oddziałującym na kobiety), Starym Mędrcem. Celem indywiduacji jest osiaggnięcie Jaźni, pełni. Proces ten Jung opisał w pracach Aion, Archetypy i nieświadomość zbiorowa, O rozwoju osobowości.

Siedem podróży Sindbada, to, zdaniem Sosnowskiego, przykład „nieudanych prób reintegracyjnych" ${ }^{2}$. Jak pamiętamy, Sindbad, niczym Bond z serii powieści Iana Fleminga i z filmów, w każdej podróży ma kochankę lub kochanki. Ich imiona to Piruza, Najdroższa, Sermina, Armina, Kaskada, Chryzeida, Urgela, Stella i Arkela, którą wreszcie poślubił. „Jestem dość kochliwy” - przyznawał Sindbad. Grodzki uważa bohatera Leśmianowskiego za „mężczyznę chorobliwie owładniętego żądzą miłosnego obcowania, ofiarę nadmiernie pobudzonego libido"53, co zbliża go do samego poety, który również był bardzo kochliwy (a nie zawsze wiązało się to z wzajemnością).

Sosnowski pisze, iż perypetie Sindbada maja pomyślny finał, zatem byłaby to wbrew jego tezie - pozytywna indywiduacja. Bohater zostaje statecznym mężem, pogodzonym z rzeczywistościa, wręcz filistrem: „Diabeł Morski już nie nawiedzał mię we śnie i nie kusił do podróży, ponieważ stałem się człowiekiem żonatym i poważnym" 54 .

Powołując się na Junga, mylił się Sosnowski, gdy uznał pociesznego Tarabuka za reprezentanta ludzkiego rozumu. Wuj Tarabuk jest raczej owładnięty manią tworzenia poezji, jest grafomanem, a nie reprezentantem rozumu. Wzięty pod pantofel przez żonę Barabakasentorynę pisał dla niej wiersze, które ona od razu darła na kawałki.

\section{Grodzki zauważał:}

Na pół mityczna postać podróżnika, tak jak postrzegał ją Leśmian - jako bajecznie bogatego, a przy tym przystojnego i beztroskiego młodzieńca pozbawionego wszelkich przesądów natury moralnej, społecznej czy religijnej, który zdradza przy tym szczególne upodobanie do przygód erotycznych - współgrała z jego psychicznymi skłonnościami oraz nonkonformistyczną postawą wobec zagadnień moralnych i estetycznych ${ }^{55}$.

Badacz uznał, iż „pod względem walorów artystycznych Przygody Sindbada

B. Lés mi a n, Klechdy sezamowe. W: Dzieła wszystkie, [t. 3], s. 242.

J. S o snowski, Sindbad zreintegrowany. (Bolesław Leśmian, „Przygody Sindbada Żeglarza”).

W zb.: Sto lat baśni polskiej. Red. G. Le s z c zy ń s ki. Warszawa 1995, s. 30-34.

Cyt. za: Grodzki, op. cit., s. 69.

Ibidem, s. 259.

Le ś mi i n, Przygody Sindbada Żeglarza, s. 205.

Grodzki, op. cit., s. 14. 
Żeglarza znacznie przewyższają pozostałe utwory prozą, jakie wyszły spod pióra Leśmiana"56. I chociaż zdania na ten temat mogą być różne: jednym podoba się atmosfera Legend tęsknoty, inni wyżej cenią Klechdy polskie - jednakże trzeba się zgodzić z tezą, iż Przygody należały do najwybitniejszych osiagnięć literackich Leśmiana i weszły do kanonu literatury dziecięcej. Z przyjemnością sięgają do nich także czytelnicy dorośli.

Do dziś opowieść ta jest klasyczną pozycją w literaturze dziecięcej. Ileż w tej ksiażce oryginalnych pomysłów (np. świetnie uchwycony został stosunek bohatera do Diabła Morskiego). Autor Przygód Sindbada Żeglarza w dobrotliwy sposób drwi z nieudolnego wuja-grafomana, który stara się utrwalić płody swej manii poetyckiej, ucząc tych wierszy dziewczęta, służące albo dając je sobie wytatuować na całym ciele. Jednocześnie Leśmian pokazuje młodym czytelnikom, że na świat można patrzeć jak na baśń. Jego dzieło jest nie tylko opracowaniem znanych opowieści wschodnich, ale przede wszystkim ich twórczym przekształceniem, pełnym swoistych określeń i sytuacji. Język - oryginalny, niesztampowy, baśniowy - wprowadza nas w świat legend, czarów i niezwykłości.

Sindbad odbywający podróże obfitujące w przygody jest ucieleśnieniem literackim marzeń młodzieńczych poety, który w listach do Miriama snuł projekty wyprawy z Kijowa przez Odessę do Konstantynopola. Być może, Leśmian wspominał przy okazji podróż swego pradziadka, Lewina Seliga Sunderlanda, Brytyjczyka, który 24 VI 1821 wsiadł na statek płynący do Hamburga. Rozpoczął podróż, zakończoną w Polsce - rodzina Sunderlandów osiadła w Warszawie i w Iłży, gdzie Lewin Selig zajął się produkcją fajansu. Bilet podróży do dziś przechowuje wnuk fotografika Jana Sunderlanda, Piotr.

Powieść Leśmiana stanowiła ostatnie ogniwo cyklu utworów egzotycznych, nawiązujących do Orientu, do przepychu, do parnasistowskiej fascynacji niezwykłością. Już wkrótce nadszedł w twórczości poety okres zainteresowania ludowością, mitologią słowiańską.

Przygody Sindbada Żeglarza wznawiane były wielokrotnie. Jeszcze w czasie wojny wydane zostały (w 1944 r.) nakładem emigracyjnego Ministerstwa Wyznań Religijnych i Oświecenia Publicznego. Wyszły drukiem w Jerozolimie, a przeznaczone były dla dzieci polskich uchodźców, które z ZSRR dotarły razem z armią generała Władysława Andersa na Bliski Wschód. Po wojnie, od r. 1950, ukazywały się nakładem „Czytelnika”. Do roku 1992 - siedmiokrotnie. Potem powieść wznawiały inne wydawnictwa.

Dzieci z zapartym tchem śledziły barwne historie i przygody bohaterów. Czytelnicy dorośli mogą również czerpać przyjemność z tej lektury, dostrzegając nawiązania do literatury, parafrazy wątków tematycznych, pytać o źródła inspiracji. Odbiorca dojrzały widzi kunszt języka i humor poety. Zauważa także metaopowieści. W baśniach wschodnich Bolesław Leśmian nie odtwarzał jedynie fabuły rodem z Tysiaca i jednej nocy. Starał się podkreślić, że przedstawiony świat nie jest realny, że czytelnik obcuje $z$ baśnią. Wielokrotnie wskazywał, jakie w baśniach obowiązu- 
ją reguły. Niekiedy utożsamiał życie $z$ baśnią, tak jak w swoich poezjach - ze snem. Pisał w dobrym - mimo śmierci ojca - okresie życia, gdy był na fali wznoszącej, której apogeum stanowił, przygotowywany w tym czasie i nieco później, tom Łąka, najwybitniejszy, moim zdaniem, utwór poetycki wydany w Dwudziestoleciu międzywojennym.

\section{Abstract \\ PIOTR LOPUSZAŃSKI Warsaw \\ LEŚMIAN'S ARABIAN NIGHTS}

The article discusses the Oriental inspirations in Bolesław Leśmian's books from the year 1912 for children and in Przygody Sindbada Żeglarza (The Adventures of Sindbad the Sailor) published in 1913, as well as in the poem Nieznana podróż Sindbada Żeglarza (Unknown Voyage of Sindbad the Sailor) from the year 1911. The pieces are based on the stories from Tysiac i jedna noc (Arabian Nights). The author attempts to establish which edition of the Eastern tales formed the basis of Leśmian's version. Reaching for the French (Contes des Mille et une nuit) and the English edition (Stories from Arabian Nights) with Edmund Dulac's illustrations prove vital since Jakub Mortkowicz used a few of the illustrations in the Polish edition of Leśmian's Klechdy sezamowe (Sesame Tales). 